\title{
Factors affecting methanol content of fermented plant beverage containing Morinda citrifolia
}

\author{
Chaiyavat Chaiyasut ${ }^{1 \star}$, Supakan Jantavong ${ }^{2}$, Chakkrapong Kruatama ${ }^{1}$, Sartjin Peerajan ${ }^{3}$, \\ Sasithorn Sirilun ${ }^{1}$ and Lalida Shank ${ }^{4}$ \\ ${ }^{1}$ Department of Pharmaceutical Sciences, Faculty of Pharmacy, Chiangmai University, Thailand. \\ ${ }^{2}$ Food and Drug Administration (FDA), Ministry of Public Health, Thailand. \\ ${ }^{3}$ Health Innovation Institute, Chiangmai, Thailand. \\ ${ }^{4}$ Department of Chemistry, Faculty of Science, Chiangmai University, Thailand.
}

Accepted 26 June, 2013

\begin{abstract}
Pectin extraction of fresh Morinda citrifolia Linn or Noni using $\mathrm{HCl}$ at various concentrations was studied. The highest pectin yield $(9.89 \% \mathrm{w} / \mathrm{w})$ was achieved by using $20 \mathrm{mM} \mathrm{HCl}$. Pectinmethylesterase (PME) activity and specific activity of raw M. citrifolia were $0.276(\mu \mathrm{mol} / \mathrm{ml}$. min) and $1.48(U \mathrm{nits} / \mathrm{mg})$, respectively whereas, in the ripen $M$. citrifolia, they were $1.006(\mu \mathrm{mol} / \mathrm{ml} . \mathrm{min})$ and $2.96(U \mathrm{nits} / \mathrm{mg})$, respectively. Four formulas (F1, F2, F3 and F4) of the fermented plant beverage (FPBs) were prepared by varying material size (blended and diced) and sterilization process $\left[72^{\circ} \mathrm{C}\right.$ and using potassium metabisulfite (KMS)] using factorial design. Soluble pectin in FPBs using blended material (F3 and F4) was higher than in FPBs using diced material (F1 and F2). Soluble pectin in FPBs using pasteurization (F1 and F3) was also higher than FPBs using KMS (F2 and F4). At $24 \mathrm{~h}$ fermented period, methanol concentration in FPBs using blended material (F3 and F4) was higher than FPBs using diced material (F1 and F2). Methanol concentration in FPBs using KMS (F2 and F4) was also higher than FPBs using pasteurization (F1 and F3). After $24 \mathrm{~h}$ fermentation time, methanol concentration in FPBs using blended material (F3 and F4) could not be detected until the end of the fermentation whereas, in FPBs using diced material, methanol was found throughout the fermentation (F1 and F2). The study indicates that the most influencial factor on methanol production in FPBs was raw material size. Other factors were sterilization, PME and pectin, respectively. Thus, the recommended procedure of the fermentation of plant beverage was the use of blended raw $M$. citrifolia and pasteurization at $72^{\circ} \mathrm{C}$ for $15 \mathrm{~s}$. These conditions prevent methanol production in FPBs. Therefore, quality and safety of the FPBs will be accepted by consumers.
\end{abstract}

Key words: Morinda citrifolia, methanol, pectin, pectinmethylesterase (PME), fermented plant beverage (FPB).

\section{INTRODUCTION}

Fermented plant beverages (FPBs) are non-alcoholic beverages produced from different kinds of plants such as cereals, fruits and vegetables. The product is fermented by lactic acid bacteria (LAB) such as Lactobacillus plantarum and Lactobacillus casei (Duangjitchareon et al., 2008). In Thailand, FPBs were first produced by local Thai people for household product until they were commercially produced throughout the country. The same kinds of the beverages are produced in several countries, for example, $E M \cdot X^{\circledR}$ rice bran beverages in Japan, Vita Biosa probiotic beverage in Denmark and various FPBs in Thailand (Kantachote et al., 2010). 
The production steps of FPBs are usually mixing plant, sugar and water in the ratio of $3: 1: 10(\mathrm{w} / \mathrm{w} / \mathrm{v})$ with or without $10 \%$ starter culture in a plastic bucket. Then, the fermentation is incubated at $30 \pm 2{ }^{\circ} \mathrm{C}$ for three to six months depending on plant type. The beverage is produced among the farmers throughout the country. It has been recommended for serving size at $30 \mathrm{ml} /$ day. Several plants can be used to produce FPBs. Morinda citrifolia. Linn or Noni is the most famous raw material of FPBs in Thailand. $M$. citrifolia has been extensively used in folk and traditional medicine for over 2,000 years. The major components in the fresh plant have been determined such as scopoletin, octanoic acid, potassium, vitamin $\mathrm{C}$, terpenoids, alkaloids, anthraquinones, $\beta$ sitosterol, carotene, vitamin A, flavone glycosides, linoleic acid, alizarin, amino acids, acubin, $L$-asperuloside, caproic acid, caprylic acid, ursolic acid, rutin, and a putative proxeronine (Mian-Ying et al., 2002) but data on the $M$. citrifolia plant beverage have not been investigated. M. citrifolia has been reported to have broad therapeutic effects, against constipation, hypertension, stomach ulcers, rheumatism, sore throat, bacterial, viral, fungal, inflammatory, autoimmune and cancer (Wang and Su, 2001; Wang et al., 2002; Kamiya et al., 2004). People who consume FPBs believe that it is a health promoting beverage and helps in curing some diseases.

FPBs contain bioactive compounds derived from the raw material and $L A B$ activities (Duangjitchareon et al., 2008). It was claimed to relieve constipation, relieve diabetes, treat colitis, enhance specific and nonspecific immune response, inhibit pathogen growth and translocation, stimulate gastrointestinal immunity, reduce chance of infection from common pathogens, reduce risk of certain cancers (colon, bladder), detoxify carcinogens, suppress tumors, lower serum cholesterol concentrations, reduce blood pressure in hypertensives (Duangjitchareon et al., 2009). Most of consumers are elderly people. Therefore, safety is the most important issue. Chemical quality control of the product is very important for consumer safety, especially methanol, a colorless volatile compound with a mild alcohol odor. It is toxic to humans and is readily absorbed by ingestion and inhalation and more slowly, through the skin. In the body, methanol is metabolized at the liver, and converted first to formaldehyde and then to formate. High levels of formate after excessive methanol intake can cause severe toxicity and even death (Lamiable et al., 2004; Zocca et al., 2007). Therefore, lowest level of methanol in food is preferable. Maximum level of methanol in FPBs according to Thai community product standard (TCPS 481/2004) was $240 \mathrm{mg} / \mathrm{L}$ whereas Australia New Zealand Food Authority (ANZFA) permitted the maximum concentration of methanol in spirit beverages at $8 \mathrm{~g} / \mathrm{L}$ of ethanol in the beverage [maximum ethanol level in Thai FPBs is $3 \%(\mathrm{v} / \mathrm{v})]$.

Methanol is an undesirable component in the production of FPBs. Methanol is naturally produced in the anaerobic metabolism of many varieties of bacteria and is ubiquitous in the environment (Vries, 1986; Schrader et al., 2009). It is also presented as a consequence of enzymatic degradation of pectins. Pectinmethylesterase (PME, EC: 3.1.1.11) de-esterifies pectins to low-methoxyl pectins, resulting in the formation of methanol (Micheli, 2001).

In this paper, we studied the factors that contribute to methanol production in FPBs containing M. citrifolia. Raw material size, sterilization process, PME of raw material and soluble pectin at various fermentation times were studied. Knowing factors which affect the formation of methanol during the fermentation will be useful for the assessment of safety and quality of FPBs.

\section{MATERIALS AND METHODS}

\section{Determination of pectin in fresh $M$. citrifolia}

\section{Sample preparation}

M. citrifolia sample was purchased from a local market. It was washed with distilled water and cut into small pieces. The sliced samples were then dried to constant weight at $60^{\circ} \mathrm{C}$ for $48 \mathrm{~h}$. Then, they were grinded with grinder and stored in closed container at $4^{\circ} \mathrm{C}$ until use.

\section{Removal of impurity}

$1 \mathrm{~g}$ of sample was mixed with $2 \mathrm{ml} 95 \%$ ethanol. After that, the mixture was boiled in water bath at $70^{\circ} \mathrm{C}$ for $10 \mathrm{~min}$. The mixture was then filtered through four layers of cheesecloth. The pomace was collected, and $20 \mathrm{ml}$ of $30 \%$ ethanol was added to the pomace. It was kept at room temperature for $30 \mathrm{~min}$ and the pellet was collected.

\section{Pectin extraction using hydrochloric acid (modified from Bhatia et al., 1959)}

The $M$. citrifolia pellet was mixed with $\mathrm{HCl}$ with the ratio $1: 30(\mathrm{w} / \mathrm{v})$. Various concentrations of $\mathrm{HCl}(5,20,50$ and $100 \mathrm{mM})$ were used. The mixture was then boiled in water bath for $1 \mathrm{~h}$. The mixture was immediately filtered through cheesecloth.

\section{Pectin precipitation (modified from Alexander and Sulebele, 1980)}

The filtrate was precipitated with cooled $95 \%$ ethanol $(40: 45, \mathrm{v} / \mathrm{v})$ and continuously stirred until pectin gel occurred. The sample was then cooled in refrigerator for $12 \mathrm{~h}$. Pectin pellet was then filtered under vacuum and washed with $80 \%$ ethanol $(1: 15 \mathrm{v} / \mathrm{v})$, followed by $95 \%$ ethanol. Finally, pectin pellet was dried to constant weight at $40^{\circ} \mathrm{C}$.

Determination of pectinmethylesterase (PME) in fresh $M$. citrifolia

\section{PME Extraction}

The extraction of the enzyme was performed by modifying method of Verlent et al. (2004). $60 \mathrm{~g}$ of M. citrifolia in $100 \mathrm{ml}$ cooled distilled water was blended and filtered through cheesecloth to remove 
Table 1. Description of fermented plant beverage formulation containing $M$. citrifolia.

\begin{tabular}{lll}
\hline \multirow{2}{*}{ Formula } & \multicolumn{2}{c}{ Process } \\
\cline { 2 - 3 } & Raw material preparation & Sterilization process \\
\hline 1 (F1) & Diced & Pasteurization $\left(72^{\circ} \mathrm{C}\right.$ for $\left.15 \mathrm{~s}\right)$ and cool shock \\
$2(\mathrm{~F} 2)$ & Diced & Potassium metabisulfite \\
$3(\mathrm{~F} 3)$ & Blended & Pasteurization $\left(72^{\circ} \mathrm{C}\right.$ for $\left.15 \mathrm{~s}\right)$ and cool shock \\
$4(\mathrm{~F} 4)$ & Blended & Potassium metabisulfite \\
\hline
\end{tabular}

remove solid particles. The filtrate was then centrifuged at 10,000 $\mathrm{xg}$ at $4^{\circ} \mathrm{C}$ for $20 \mathrm{~min}$. The pellet was kept in $100 \mathrm{ml}$ of $0.003 \mathrm{M}$ phosphate buffer $\mathrm{pH}$ 7.5. $1 \%(\mathrm{w} / \mathrm{v})$ polyvinylpolypyrolidone (PVPP) was then added. The mixture was stirred using magnetic stirrer at $4^{\circ} \mathrm{C}$ for $24 \mathrm{~h}$. Then, it was centrifuged at $10,000 \times \mathrm{g}$ for $20 \mathrm{~min}$. For PME activity determination, the $\mathrm{pH}$ of obtained supernatant was adjusted to 7.5 .

\section{PME activity determination}

PME activity was spectrophotometrically determined using modified method of Hagerman and Austin (1986). $2 \mathrm{ml}$ of pectin, $0.15 \mathrm{ml}$ of bromothymol blue and $1.35 \mathrm{ml}$ of phosphate buffer were mixed. The solution was heated at $60^{\circ} \mathrm{C}$ for 2 min. The activity was monitored by adding $0.5 \mathrm{ml}$ of sample and the absorbance was read at 620 $\mathrm{nm}$ for 1 min afterwards. PME activity was calculated as that for Dgalacturonic acid $1 \mu \mathrm{mol}$ per $1 \mathrm{~min}$ as follows:

PME activity $($ unit $/ \mathrm{ml})=\frac{\text { D-galacturonic acid }(\mu \mathrm{mol} / \mathrm{ml}) \times \text { Total solution volume }(\mathrm{ml})}{\text { Enzyme added }(\mathrm{ml}) \times \text { Reaction time }(\mathrm{min})}$

\section{Total protein determination}

The protein contents were determined according to Bradford (1976). $0.50 \mathrm{ml}$ of sample was mixed with $0.10 \mathrm{ml}$ of distilled water, $0.10 \mathrm{ml}$ of $0.15 \mathrm{M} \mathrm{NaCl}$ and $4.30 \mathrm{ml}$ of dye $(0.01 \% \mathrm{w} / \mathrm{v}$ Coomassie brilliant blue G-250). The solution was kept for $10 \mathrm{~min}$. Then absorbance was read at $595 \mathrm{~nm}$ (using bovine serum albumin as standard). PME specific activity (units $/ \mathrm{mg}$ ) was calculated according to the following equation:

Total PME (Units)

PME specific activity (Units/mg) $=\frac{\text { Total protein }(\mathrm{mg})}{\text { Total PME (Units) }}$

Determination of pectin in fermented plant beverage (FPBs)

\section{Preparation of fermented M. citrifolia beverage}

FPBs containing $M$. citrifolia was prepared by mixing fresh $M$. citrifolia, sugar, water and Lactobacillus plantarum starter culture $\left(10^{6} \mathrm{cfu} / \mathrm{ml}\right)$ with the ratio $3: 0.26: 10: 1.3$ by weight. The experimental FPB was assigned into four formulas by varying raw material preparation (diced or blended) and sterilization process (pasteurization and cool shock or using potassium metabisulfite (KMS)) using factorial design as shown in Table 1. The FPBs was kept in close and sterile fermentor at $37^{\circ} \mathrm{C}$. The samples were collected at $0,12,24,36,42,72,120,240,360,480,600$ and 720 h, respectively. Determination of pectin as polygalacturonic acid using
colorimetric method

$200 \mu \mathrm{l}$ sample was added to $1.2 \mathrm{ml}$ of $0.125 \mathrm{M}$ sulfuric acid/tetraborate. The mixture was cooled on ice for $2 \mathrm{~min}$ then heated at $100^{\circ} \mathrm{C}$ for $5 \mathrm{~min}$ and cooled again. Afterwards, the sample was mixed with $20 \mu \mathrm{l}$ of 3-phenylphenol (using acetateEDTA buffer as blank). Then, the absorbance was read at $520 \mathrm{~nm}$. Galacturonic acid $(0.1 \mathrm{mg} / \mathrm{ml})$ was used as a standard. Pectin determination was modified from Monsoor et al. (2001).

\section{Determination of methanol using gas chromatography (GC)}

Methanol concentration was determined by modified method from Wang et al. (2004) and Okunowo and Osuntoki (2007). A PerkinElmer GC (Sigma 3B) equipped with a flame ionization detector and an automatic injection system was used. Column: Carbowax 20M column, was set at $120^{\circ} \mathrm{C}$. The injector was set at $180^{\circ} \mathrm{C}$ and the detector at $200^{\circ} \mathrm{C}$. Isobutanol $(0.5 \% \mathrm{v} / \mathrm{v})$ and isopropanol $(0.5 \% \mathrm{v} / \mathrm{v})$ were used as internal standards. The standard methanol was prepared in the range of concentrations of 10 to $1000 \mathrm{mg} / \mathrm{L}$. Helium was used as carrier gas at a flow rate of $0.9 \mathrm{ml} / \mathrm{min}$.

\section{Statistical analysis}

All experiments were performed in triplicate. One-way analysis of variance was used followed by the Duncan' multiple comparison test to analyze significant differences between treatments at significant level of $95 \% \quad(p<0.05)$. Pearson's correlation was analyzed for relation between pectin and methanol level in FPBs (only F1 and F2). SPSS version 17.0 for Windows was used.

\section{RESULTS}

\section{Determination of pectin in fresh M. citrifolia}

Pectin extracted from $M$. citrifolia using $\mathrm{HCl}$ at various concentrations was determined. Pectin yields from each $\mathrm{HCl}$ concentration were significantly different. Figure 1 shows that pectin yield increased when $\mathrm{HCl}$ concentration was changed from 5 to $20 \mathrm{mM}$. However, using higher $\mathrm{HCl}$ concentrations (50 and $100 \mathrm{mM}$ ), pectin yield decreased. The result showed that the highest pectin yield, using $20 \mathrm{mM} \mathrm{HCl}$ was $9.89 \%$ and the lowest pectin yield, using $100 \mathrm{mM} \mathrm{HCl}$ was $6.55 \%$.

\section{Determination of pectinmethylesterase (PME) in fresh M. citrifolia}

PME activity in raw and ripen $M$. citrifolia was measured. 


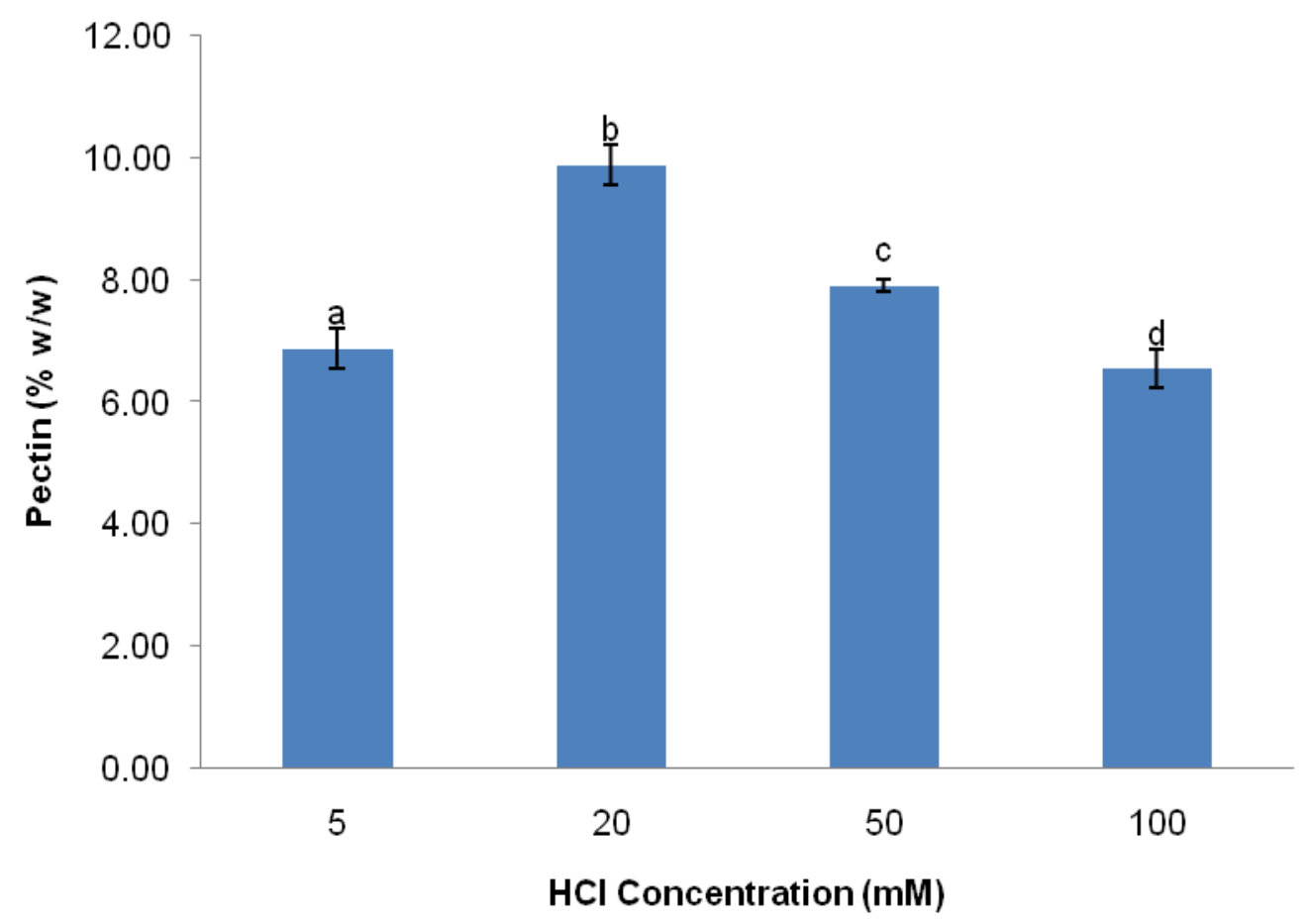

Figure 1. Pectin yields (\% w/w of $M$. citrifolia fresh weight) extracted by $\mathrm{HCl}$ at concentrations 5,20 , 50 and $100 \mathrm{mM}$. Bars indicate standard deviation of triplicate experiment. Means different with small characters indicate significant different $(p<0.05)$ between treatment.

The result showed that PME activity of raw $M$. citrifolia was $0.276 \mu \mathrm{mol} / \mathrm{ml}$. min with specific activity of 1.48 Units/mg. PME activity of ripen $M$. citrifolia was 1.006 $\mu \mathrm{mol} / \mathrm{ml}$. min with specific activity of 2.96 Units $/ \mathrm{mg}$.

\section{Determination of pectin in fermented plant beverage}

Changes in pectin content in FPBs, determined as soluble pectin, were significantly different in all treatments. Figure 2 shows the soluble pectin in FPBs containing $M$. citrifolia with different production process. Pectin was found within the range of 0.5 to $3.5 \mathrm{mg} / \mathrm{ml}$. Soluble pectins of all formula were exponentially decreased in the early fermentation. After $72 \mathrm{~h}$ fermentation period, soluble pectin in F1, F3 and F4 were slightly decreased along the fermentation time but soluble pectin in F2 greatly decreased. At the end of fermentation (30 days, $720 \mathrm{~h}$ ), soluble pectin in FPBs using blended material (F3 and F4) was higher than FPBs using diced material (F1 and F2). When compared with the sterilization process between using pasteurization and using KMS, the soluble pectin of the formulas using pasteurization was higher than for the other one. It was observed from Figure 2 that soluble pectin of F3 was higher than that of $\mathrm{F} 4$. In the same manner, soluble pectin of $F 1$ was higher than that of F2. At the end of fermentation, the highest soluble pectin was found in F3
$(2.015 \mathrm{mg} / \mathrm{ml})$ and the lowest soluble pectin was found in F2 $(0.789 \mathrm{mg} / \mathrm{ml})$.

\section{Determination of methanol using GC}

Figure 3 shows the chromatogram with given GC conditions. Methanol (A), iso-propanol (B; internal standard) and iso-butanol ( $C$; internal standard) gave retention time at $2.63,7.46$ and $12.52 \mathrm{~min}$, respectively. Various manufacturing process was performed as described in Table 1. Methanol concentration of FPBs was determined as shown in Figure 4. Methanol concentration in $\mathrm{F} 1$ and $\mathrm{F} 2$ gradually increased from $\mathrm{Oh}$ to the end of the fermentation ( 30 days, $720 \mathrm{~h}$ ) and has the significantly highest concentration at 40.90 and $264.80 \mathrm{mg} / \mathrm{L}$, respectively. Methanol in F3 and F4 rapidly increased and had the highest concentration at $24 \mathrm{~h}$, at 475.28 and $853.41 \mathrm{mg} / \mathrm{L}$, respectively. Then, the methanol concentrations dropped to undetectable level and could not be detected until the end of the fermentation. The highest methanol concentration throughout the fermentation was found in F2, using diced M. citrifolia as raw material and using KMS as sterilization agent. The lowest methanol concentration was found in F3 and F4. Both used blended $M$. citrifolia as raw material. The Pearson's correlation between soluble pectin and methanol in F1 and F2 were -0.4502 ( $p=$ 


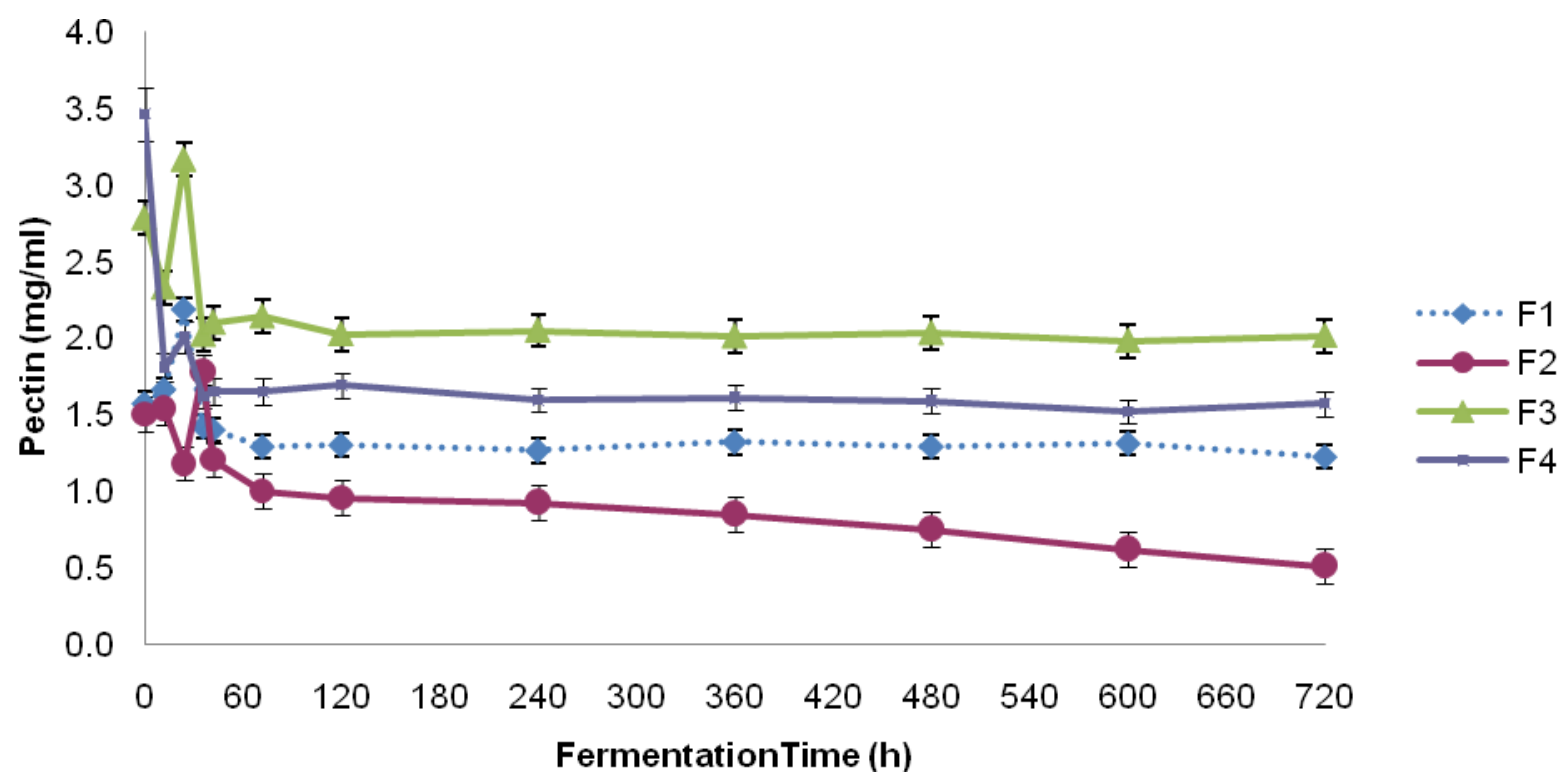

Figure 2. Soluble pectin in fermented plant beverage containing $M$. citrifolia at various fermentation time. Bars indicated standard deviation of triplicate experiment. See Table 1 for F1 to F4.

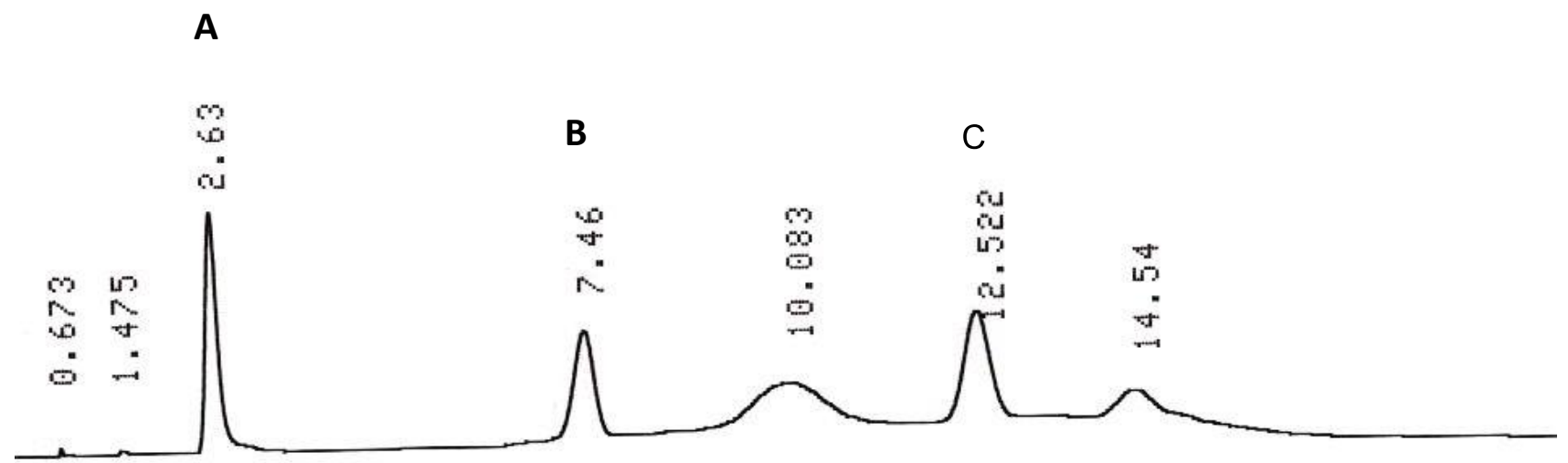

Figure 3. Gas chromatogram of fermented plant beverage containing $M$. citrifolia sample. $A=$ Methanol; $B=$ iso-propanol; $C=i s o-$ butanol.

$0.1227)$ and $-0.4952(p=0.002)$, respectively.

\section{DISCUSSION}

\section{Determination of pectin in fresh M. citrifolia}

Pectins occur as structural polysaccharide in higher plants cell walls. During ripening, pectin is broken down by PME to low-methoxyl pectin (Micheli, 2001), resulting in the formation of methanol. The result show high content of pectin in M. citrifolia $(9.89 \%)$ extracted with $\mathrm{HCl}$ at concentration of $20 \mathrm{mM}$. This concentration allowed suitable $\mathrm{pH}$ for pectin precipitation (Faravash and
Ashtiani, 2006). When compared with another pectin plant sources such as guava $(4.36 \%)$, tomato $(0.3 \%)$, apple $(0.5 \%)$, carrot $(0.8 \%)$, cherries $(0.4 \%)$ (Holloway et al., 1983), M. citrifolia has much more pectin contents $(9.89 \%)$. The aim of the determination of pectin content in this plant is to indicate possibility of methanol production in FPBs related pectin content.

\section{Determination of pectinmethylesterase (PME) in fresh M. citrifolia}

The result indicate that age of $M$. citrifolia is related to PME activity. The enzyme is present in most plant 


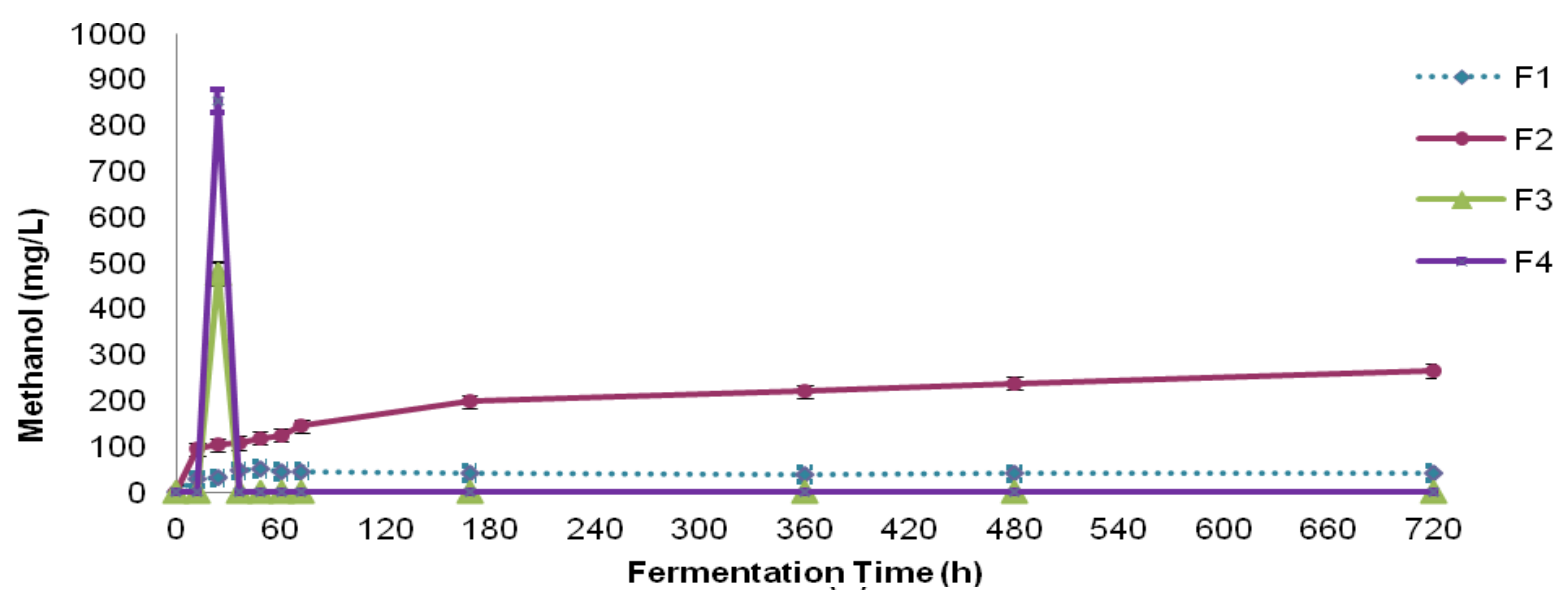

Figure 4. Methanol content ( $\mathrm{mg} / \mathrm{L})$ of fermented plant beverage containing $M$. citrifolia at various fermentation time. Bars indicate standard deviation of triplicate experiment. See Table 1 for F1 to F4.

tissues. It likely plays an important role in plant metabolism. PME removes methyl groups from the pectic component of cell wall during fruit ripening which can then be depolymerized by polygalacturonase, decreasing the intercellular adhesivity and tissue rigidity (Assis et al., 2001). There was a close correlation reported between PME activity and methanol levels in fruit tissues from both wild-type and a PME antisense mutant tomato, indicating that $\mathrm{PME}$ is on the primary biosynthetic pathway for methanol production in tomato fruit (Frenkel et al., 1998). For PME activity determination in $M$. citrifolia, the result show that PME activity and specific activity in ripen $M$. citrifolia was higher than in raw $M$. citrifolia. This may result in higher methanol production in FPBs.

Thus, age of plant (raw material) is an important factor for methanol production in FPBs according to PME activity. Therefore, choosing raw $M$. citrifolia that contain low PME will be able to prevent methanol production in FPBs. Besides, pasteurization of fermentation is regularly using high temperature at $72^{\circ} \mathrm{C}$ for $15 \mathrm{~s}$. PME has high activity at the temperature between 50 and $60^{\circ} \mathrm{C}$. The enzyme loss activity is at the temperature higher than $70^{\circ} \mathrm{C}$ (Tijskens et al., 1999; Amaral et al., 2005). Sterilization using temperature higher than $80^{\circ} \mathrm{C}$ can complete inactivate PME but may cause decomposition of bioactive component in FPBs. pH of FPBs is normally in the range of 3 to 4 . These $\mathrm{pH}$ range also affect $\mathrm{PME}$ activity. In general, PME has been found to have an optimum pH ranging from 7.5 to 9.0 (Amaral et al., 2005; Arotupin et al., 2008).

\section{Determination of pectin in fermented plant beverage}

Four formulas of FPBs with different material size and sterilization process were studied. When comparing soluble pectin between FPBs containing blended and diced material, it was found that soluble pectin in FPBs containing blended material (F3 and F4) was higher than FPBs containing diced material (F1 and F2). This might be explained thus: mechanic force from blender might break long-chain pectin to lower chain pectins allowing lower carbon pectins to dissolve more. Surface area of small pectin size might also affect pectin releasing in FPBs.

For sterilization process, FPBs using pasteurization ( $\mathrm{F} 1$ and F3) had more soluble pectin than FPBs using KMS (F2 and F4). FPBs using KMS, soluble pectin might be used as PME substrate. In contrast, in FPBs using high temperature during pasteurization $\left(72^{\circ} \mathrm{C}\right)$, PME was inactivated, resulting in the remaining soluble pectin which is higher than the other one. Moreover, high temperature more than $60^{\circ} \mathrm{C}$ enhanced pectin solubility (Fox, 1994). These could be a reason for higher soluble pectin in FPBs using high temperature sterilization.

\section{Determination of methanol using GC}

Considering factors affecting methanol production in FPBs, it was found that raw material size has effect on methanol concentration. FPBs using blended material and sterilization using either pasteurization (F3) or KMS (F4) had high methanol concentration in the early fermentation period $(24 \mathrm{~h})$.

After that, the methanol concentration dropped to undetectable level until the end of fermentation. This might be explained that blended material released whole pectin and PME into FPBs, resulting in high production of methanol within $24 \mathrm{~h}$. When comparing between F3 and F4, FPBs using pasteurization (F3) inactivated PME activity resulting in lower methanol production than FPBs using KMS (F4). In FPBs using diced material, methanol 
was found throughout the fermentation period. It might be implied that pectin and PME were gradually released along the fermentation. Methanol concentration in FPBs using KMS (F2) was gradually increased along the fermentation. Nevertheless, methanol in FPBs using pasteurization (F1) was found constant after $72 \mathrm{~h}$. When comparing the sterilization process between using pasteurization (F1) and using KMS (F2), PME activity in FPBs using pasteurization (F1) was inactivated. Therefore, the methanol concentration of the formula using KMS (F2) was higher than the other one. The result indicate that the most effective factor on methanol production was material size. For the formula using blended material, methanol could not be detected at the end of the fermentation $(720 \mathrm{~h})$ even if high methanol concentration was found within $24 \mathrm{~h}$.

In FPBs using diced material, methanol was found throughout the fermentation. The next factor is sterilization process. FPBs with blended material using KMS (F4) has higher methanol concentration than FPBs using pasteurization (F3) at $24 \mathrm{~h}$. Afterwards, methanol could not be detected until the end of the fermentation. Among FPBs using diced material, methanol concentration of FPBs using KMS was greatly higher than FPBs using pasteurization and tended to increase along the fermentation time. Pectin and PME also had effect on methanol production. Higher pectin in FPBs using blended material (F3 and F4) had higher methanol concentration in the early fermentation than FPBs using diced material (F1 and F2). When comparing the sterilization process using the same material size. FPBs using KMS (F2 and $\mathrm{F} 4$ ) had higher pectin yield than FPBs using pasteurization ( $F 1$ and F3) but had lower methanol concentration. The Pearson's correlation between soluble pectin and methanol level in FPBs (F1 and F2) significantly showed low relation between the factors. This could indicate that PME has more effect on methanol production than soluble pectin in FPBs. Maximum methanol concentration according to Thai community product standard (TCPS 481/2004) was 240 $\mathrm{mg} / \mathrm{L}$. It was found that FPBs with diced material and using KMS (F2) had methanol concentration higher than the standard regulation.

\section{Conclusion}

This study indicates that the main factors which affect methanol production in FPBs containing $M$. citrifolia was raw material size. FPBs using blended material had lower methanol concentration at the end of fermentation than FPBs using diced material. Next factor is the sterilization process. FPBs using KMS had higher methanol concentration than FPBs using pasteurization. PME activity in raw and ripen, as well as soluble pectin in FPBs had effect on methanol production as well.

From our experiment, we recommend appropriate con- condition for the fermentation of plant beverage by using blended raw M. citrifolia and pasteurization with temperature higher than $70^{\circ} \mathrm{C}$ in order to produce $\mathrm{FPBs}$ containing low methanol with the characteristic of the FPBs been: clear brown solution, sour flavor and a smell originating from plant with little smell of ester from fermentation. Good Manufacturing Practice (GMP) and Good Hygiene Practice (GHP) could not also be negligible for high quality and safety of the products that is acceptable for domestic and international consumer.

\section{ACKNOWLEDGEMENTS}

This study was granted by the Food and Drug Administration (FDA), Ministry of Public Health and National Science and Technology Development Agency (NSTDA), Ministry of Science and Technology. We would like to thank the Faculty of Pharmacy and Faculty of Science, Chiangmai University, Thailand for facility.

\section{REFERENCES}

Alexander MM, Sulebele GA (1980). Characterization of pectins from Indian citrus peels. J. Food Sci. Tech. 17:180-182.

Amaral SHD, Assis SAD, Oliveira OMMDF (2005). Partial purification and characterization of pectin methylesterase from orange (Citrus sinensis) CV Pera-Rio. J. Food Biochem. 29:367-380.

Arotupin DJ, Akinyosoye FA, Onifade AK (2008). Purification and characterization of pectinmethylesterase from Aspergillus repens isolated from cultivated soil. Afr. J. Biotechnol. 7:1991-1998.

Assis SA, Lima DC, Faria Oliveira OMM (2001). Activity of pectinmethylesterase, pectin content and vitamin $\mathrm{C}$ in acerola fruit at various stages of fruit development. Food Chem. 74:133-137.

Bhatia BS, Krishnamurthy GV, Lal G (1959). Precipitation of pectin from raw papaya (Carica papaya) by aluminium chloride precipitation method. Food Sci. 13:553-556.

Bradford MM (1976). A rapid and sensitive method for the quantitation of microgram quantities of protein utilizing the principle of protein-dye binding. Anal. Biochem. 72:248-254

Duangjitchareon Y, Kantachote D, Ongsakul M, Poosaran N, Chaiyasut C (2008). Selection of Probiotic Lactic Acid Bacteria Isoalated from Fermented Plant Beverages. Pakistan J. Biol. Sci. 11: 652-655.

Duangjitchareon Y, Kantachote D, Ongsakul M, Poosaran N, Chaiyasut C (2009). Potential use of probiotic Lactobacillus plantarum SS2 isolated from a fermented plant beverage: safety assessment and persistence in the murine gastrointestinal tract. World J. Microb. Biot. 25:315-321.

Faravash RS, Ashtiani FZ (2006). The effect of $\mathrm{pH}$, ethanol volume and acid washing time on the yield of pectin extraction from peach pomace. Int. J. Food Sci. Tech. 42:1177-1187.

Fox G (1994). Process for recovery of pectin extract from sugar beet and its use. German Federal Republic Patent. DE 43 (13)549.

Frenkel C, Peters JS, Tieman DM, Tiznado ME, Handa AK (1998). Pectin Methylesterase Regulates Methanol and Ethanol Accumulation in Ripening Tomato (Lycopersicon esculentum) Fruit. J. Biol. Chem. 273:4293-4295.

Hagerman AE, Austin PJ (1986). Continuous spectrophotometric assay for plant pectin methyl esterase. J. Agr. Food Chem. 34:440-444.

Holloway WD, Tasman-Jones C, Maher K (1983). Pectin Digestion in Humans. Am. J. Clin. Nutr. 37:253-255.

Kamiya K, Tanaka Y, Endang H, Umar M, Satake T (2004). Chemical constituents of Morinda citrifolia fruits inhibit copper-induced lowdensity lipoprotein oxidation. J. Agr. Food Chem. 52:5843-5848.

Kantachote D, Prachyakij P, Charernjiratrakul W, Ongsakul M, 
Duangjitcharoen Y, Chaiyasut C, Nitoda T, Kanzaki H (2010). Characterization of the antiyeast and probiotic properties of a starter Lactobacillus plantarum DW3 for possible use in fermented plant beverages. Electron. J. Biotechno. 13:1-15.

Lamiable D, Hoizey G, Marty H, Vistelle R (2004). Acute methanol intoxication. EMC-Toxicol. Pathol. 1:7-12.

Mian-Ying W, West BJ, Jensen CJ, Nowicki D, Chen S, Palu AK, Anderson G (2002). Morinda citrifolia (Noni): A literature review and recent advances in Noni research. Acta Pharmacol Sin. pp.11351136.

Micheli F (2001). Pectin methylesterases: cell wall enzymes withimportant roles in plant physiology. Trends Plant Sci. 6:414-419.

Monsoor MA, Kalapathy U, Proctor A (2001). Determination of polygalacturonic acid content in pectin extracts by diffuse reflectance Fourier transform infrared spectroscopy. Food Chem. 74:233-238.

Okunowo WO, Osuntoki AA (2007). Quantification of alcohols in orange wine fermented by four strains of yeast. Afr. J. Biochem. Res. 1:95100.

Schrader J, Schilling M, Holtmann D, Sell D, Filho MV, Marx A, Vorholt JA (2009). Methanol-based industrial biotechnology: current status and future perspectives of methylotrophic bacteria. Trends Biotechnol. 27:107-115.
Tijskens LMM, Rodis PS, Hertog MLATM, Proxenia N, VAN DIJK C (1999). Activity of pectin methyl esterase during blanching of peaches. J. Food Eng. 39:167-177.

Verlent I, Loey A, Smout C, Duvetter T, Hendrickx M (2004). Purified tomato polygalacturonase activity during thermal and high-pressure treatment. Biotechnol. Bioeng. 86:63-71.

Vries GE (1986). Molecular biology of bacterial methanol oxidation. FEMS Microbiol. Lett. 39:235-258.

Wang MY, Su C (2001). Cancer preventive effect of Morinda citrifolia (Noni). Ann. N.Y. Acad. Sci. 952:161-168.

Wang MY, West BJ, Jensen CJ, Nowicki D, Su C, Palu AK, Anderson G (2002). Morinda citrifolia (Noni): A literature review andrecent advances in Noni research. Acta Pharmacol. Sin. 23:1127-1141.

Wang ML, Wang JT, Choong YM (2004). A rapid and accurate method for determination of methanol in alcoholic beverage by direct injection capillary gas chromatography. J. Food Compos. Anal. 17:187-196.

Zocca F, Lomolino G, Curioni A, Spettoli P, Lante A (2007). Detection of pectinmethylesterase activity in presence of methanol during grape pomace storage. Food Chem. 102:59-65. 